\title{
Chemical Assessment in Shallow Wells at Mtoni and Kilima-Hewa Zanzibar: A Comparative Study
}

\author{
Abdul A. J. Mohamed"*, Miza A. Kombo', Ibrahim Abdul Rahman² and Lee H. Lim² \\ ${ }^{1}$ School of Natural and Social Science, Department of Natural Science, State University of Zanzibar (SUZA), Tanzania \\ ${ }^{2}$ Faculty of Science (FOS), Universiti Brunei Darussalam, Jalan Tungku, Brunei Darussalam, Tanzania
}

\begin{abstract}
Life is a water dependent process, however, pristine water for the consumption of the living organisms remains a big challenge in many countries. In Zanzibar, groundwater is a major source for drinking and other domestic purposes. However, the quality of water sources seems to deteriorate mainly due to anthropogenic activities. Therefore, assessment of ground water quality is extremely important to ascertain its safety for human consumption. In June 2014, water samples from shallow wells were collected from two different areas (Kilimahewa and Mtoni) in Zanzibar Island. In this study, nine chemical parameters $\mathrm{Ca}, \mathrm{Cd}, \mathrm{Cr}$ (III), $\mathrm{Cu}, \mathrm{Li}, \mathrm{Mg}, \mathrm{Pb}$, $\mathrm{Sr}$, and $\mathrm{Zn}$ have been analyzed. Furthermore, some dietary benefits, and the possible risks associated with the consumption of water containing the analyzed parameters have been highlighted. The parameters were analyzed by ICP-OES (Thermo Scientific iCAP 6000). Some of the analyzed parameters in some water sources were below detection limit (BDL) of the ICP-OES. The ranges of the parameters were; Ca: $0.0045-240.17 \mathrm{mgL}^{-1}$; Cd: 0.0007 - $48.59 \mathrm{mgL}^{-1} ; \mathrm{Cr}$ (III): BDL - $0.032 \mathrm{mgL}^{-1} ; \mathrm{Li}: 0.0004-0.0613 \mathrm{mgL}^{-1} ; \mathrm{Mg}: 0.0047-12.8 \mathrm{mgL}^{-1} ; \mathrm{Pb}: \mathrm{BDL}$ $-0.0178 \mathrm{mgL}^{-1}$; Sr: $0.0073-0.9604 \mathrm{mgL}^{-1}$ and $\mathrm{Zn}: 0.0017 \mathrm{mgL}^{-1}-0.0499 \mathrm{mgL}^{-1}$. With the intention of evaluating its quality, the assessed water quality parameters were compared with either World Health Organization (WHO) guidelines, and or other drinking water guidelines. In general, the values of analyzed parameter were within the recommended guidelines. However, the levels of cadmium and lead at Kilima-hewa sampling points are beyond the guideline levels, while the levels calcium had exceeded the recommended guidelines. Therefore, there is an urgent need for the water quality to be mitigated at affected water sources.
\end{abstract}

\section{Keywords}

Zanzibar, Dietary benefits, WHO, Shallow wells, Strontium, Lead

\section{Introduction}

Groundwater is the main source of water in Zanzibar Island, it is necessary for different domestic purposes. Shallow hand dug wells have been increasingly used as important water sources especially during rainy seasons. Elevated concentration of nutrients and metals in surface and groundwater is common in many countries of the world, and can serve as indicator of, or may lead to water quality problem. The potential nonpoint and point sources of groundwater pollution depends on factors such the depth and pumping rate of the well, the size of the source area and local hydro-geologic conditions.

Septic effluent, animal waste, municipal landfill leachate is among the potential sources which cause groundwater contamination [1]. Due to long-range transport process and the driving force of atmospheric precipitation, contaminants can migrate to the groundwater sources. Inside the aquifers, they can still be transported horizontally through permeable soils to very remote areas where they can result in to serious and unexpected heath effects.

Accelerated and uncontrolled human activities such as stock farming, urbanization, and solid waste disposal near the water wells have a strong impact on the quality groundwater sources [2]. Moreover, acid rain, mine drainage, agricultural, industrial, and domestic effluents have all contributed to some amount to the deterioration of the quality in water bodies [3]. The disproportionate and inappropriate use of insecticides, and pesticides chemical fertilizers, animal manures, and poorly built or poorly located septic systems for household wastewater have not only exhausted groundwater availability, but also made its quality inferior and inadequate [4].

Recent study has also pointed out on the effect of leachate from septic effluents and landfills area to the groundwater sources in Zanzibar [5]. Nevertheless, an unsafe disposal of electronic equipments can significantly affect the quality of groundwater.

*Corresponding author: Abdul A. J. Mohamed, School of Natural and Social Science, Department of Natural Science, State University of Zanzibar (SUZA), Tanzania, E-mail: jumabdull@yahoo.com

Received: December 21, 2015: Accepted: February 25, 2016: Published: February 28, 2016

Copyright: (C) 2016 Mohamed AAJ, et al. This is an open-access article distributed under the terms of the Creative Commons Attribution License, which permits unrestricted use, distribution, and reproduction in any medium, provided the original author and source are credited. 
The sources of cadmium can be of natural (soil and rocks) or anthropogenic origins (fertilizers, pesticides etc [6]. Another source of cadmium is batteries [7]. Cadmium is not essential nutrient for living organism consumptions. Long-term exposure to cadmium is linked to blood pressure and the occurrence of cardiovascular diseases [8]. Whereas sources of environmental lead include gasoline, painted surfaces, solders made from lead, etc. A German study pointed out that cadmium and lead can transported in-to remote areas via airborne dust [9]. Lead is said to be neurotoxin, and exposure to lead has been associated with some ill effects such as, pediatric health problems, and complications in central nervous system (CNS) [10].

Nickel is present in environment as one of the constituents of the earth's crust. Because of the omnipresence of nickel in the earth, low levels human exposure to nickel is inevitable [11]. However, other sources of cadmium in the environment are of remarkable effect, a nickel-cadmium batteries is a good example. Exposures to nickel at low doses are probably not harmful to human beings [12]. Although copper is a vital nutritional element, at higher doses it is known to cause detrimental effects such as, respiratory and gastrointestinal disturbances, liver and renal damage [11].

Zinc is a frequently occurring element in the earth's crust, it permeates, air, water, soil, and to some extent all foods [13]. Amongst other benefits, zinc is believed to influence fetal neurobehavioral development [14]. Consumption of zinc at elevated dose can cause gastrointestinal problems (stomach cramps, nausea, and vomiting) [15]. The assessment of the suitability of the chemical quality of drinking water relies on comparison of the data of water quality analysis with those from accepted guidelines values. The guidelines are established to provide a basis for assessing drinking-water quality.

Therefore, the present study focuses at assessing the groundwater suitability for human consumption at the studied areas (Mtoni, Kilima Hewa, and Fuoni) in Zanzibar Island. This study investigated the levels of nine chemical parameters (Ca, Cd, $\mathrm{Cr}$ (III), Cu, $\mathrm{Li}, \mathrm{Mg}$, $\mathrm{Pb}, \mathrm{Sr}$, and $\mathrm{Zn}$ ) in groundwater of the studied areas.

Table 1: Guidelines for drinking water as per different organizations.

\begin{tabular}{|l|l|l|l|l|}
\hline Parameters & WHO (mg/L) & CDWQ $(\mathbf{m g} / \mathbf{L})$ & $\begin{array}{l}\text { US EPA } \\
\text { (mg/L) }\end{array}$ & $\begin{array}{l}\text { EU. DWD } \\
\text { (mg/L) }\end{array}$ \\
\hline $\mathrm{Ca}$ & 100 & 200 & N/A & N/A \\
\hline $\mathrm{Cd}$ & 0.003 & 0.005 & 0.005 & 0.005 \\
\hline $\mathrm{Cr}(\mathrm{III})$ & $\mathrm{N} / \mathrm{A}$ & $\mathrm{N} / \mathrm{A}$ & $\mathrm{N} / \mathrm{A}$ & $\mathrm{N} / \mathrm{A}$ \\
\hline $\mathrm{Cu}$ & 2.0 & 1.0 & 1.3 & 2.0 \\
\hline $\mathrm{Li}$ & $\mathrm{N} / \mathrm{A}$ & $\mathrm{N} / \mathrm{A}$ & $\mathrm{N} / \mathrm{A}$ & $\mathrm{N} / \mathrm{A}$ \\
\hline $\mathrm{Mg}$ & 50 & 50 & $\mathrm{~N} / \mathrm{A}$ & N/A \\
\hline $\mathrm{Pb}$ & 0.01 & 0.01 & 0.015 & 0.01 \\
\hline $\mathrm{Sr}$ & $\mathrm{N} / \mathrm{A}$ & $\mathrm{N} / \mathrm{A}$ & $\mathrm{N} / \mathrm{A}$ & N/A \\
\hline $\mathrm{Zn}$ & 3.0 & 5 & 5 & N/A \\
\hline
\end{tabular}

WHO: World Health Organization; CDWQ: Canadian Drinking Water Quality; US EPA: United State Environmental Protection Agency; EU DWD: European Union Drinking Water Directive; N/A: No guideline available

Table 2: Minimum and Maximum concentrations measured at Kilima-hewa area and Mtoni area.

\begin{tabular}{|l|l|l|}
\hline Parameters & $\begin{array}{l}\text { Lowest concentrations } \\
\text { (mg/L) }\end{array}$ & $\begin{array}{l}\text { Highest concentrations } \\
\text { (mg/L) }\end{array}$ \\
\hline $\mathrm{Ca}$ & $0.0045^{\mathrm{a}} \& 20.508^{\mathrm{b}}$ & $90.76^{\mathrm{a}} \& 240.17^{\mathrm{b}}$ \\
\hline $\mathrm{Cd}$ & $0.0007^{\mathrm{a}} \&<\mathrm{DL}^{\mathrm{b}}$ & $48.59^{\mathrm{a}} \&<\mathrm{DL}^{\mathrm{b}}$ \\
\hline $\mathrm{Cr}$ (III) & $<\mathrm{DL}^{\mathrm{a}} \& 0.0254^{\mathrm{b}}$ & $0.032^{\mathrm{a}} \& 0.0268^{\mathrm{b}}$ \\
\hline $\mathrm{Cu}$ & $<\mathrm{DL}^{\mathrm{a}} \& 0.0005^{\mathrm{b}}$ & $0.0272^{\mathrm{a}} \& 0.0038^{\mathrm{b}}$ \\
\hline $\mathrm{Li}$ & $0.0004^{\mathrm{a}} \& 0.0075^{\mathrm{b}}$ & $0.0613^{\mathrm{a}} \& 0.0484^{\mathrm{b}}$ \\
\hline $\mathrm{Mg}$ & $0.0047^{\mathrm{a}} \& 2.325^{\mathrm{b}}$ & $10.69^{\mathrm{a}} \& 12.800^{\mathrm{b}}$ \\
\hline $\mathrm{Pb}$ & $<\mathrm{DL}^{\mathrm{a}, \mathrm{b}}$ & $0.0178^{\mathrm{a}} \& 0.0034^{\mathrm{b}}$ \\
\hline $\mathrm{Sr}$ & $0.1722^{\mathrm{a}} \& 0.0073^{\mathrm{b}}$ & $0.9604^{\mathrm{a}} \& 0.0421^{\mathrm{b}}$ \\
\hline $\mathrm{Zn}$ & $0.0017^{\mathrm{a}} \& 0.0019^{\mathrm{b}}$ & $0.0499^{\mathrm{a}} \& 0.0098^{\mathrm{b}}$ \\
\hline
\end{tabular}

a and ${ }^{\mathrm{b}}$ stand for respective concentrations at Kilima-hewa and Mtoni respectively; DL: Detection Limit

\section{Materials and Methods}

In June 2014, water samples were collected from shallow wells of two areas of Zanzibar Island namely Kilima-hewa and Mtoni, in which five water samples from each area were taken. Collection and preservation of the samples were carried out according to standard methods [16]. Chemical analysis was performed in the laboratory according to the standard methods for the examination of water and wastewater [17]. Samples for the analysis of chemical parameters were filtered using disposable Merck $0.45 \mu \mathrm{m}$ filter Millipore. Thus, the concentrations obtained correspond to the dissolved concentration in the respective ground water sites. The collected groundwater samples were analyzed for $\mathrm{Ca}, \mathrm{Cd}, \mathrm{Cr}$ (III), $\mathrm{Cu}, \mathrm{Li}, \mathrm{Mg}, \mathrm{Pb}, \mathrm{Sr}$, and $\mathrm{Zn}$. ICPOES (Thermo Scientific iCAP 6000) was used to quantify the levels of the analyzed ions. Standard calibration procedure for the ICP-OES was conducted prior sample analysis.

\section{Discussion}

The selected parameters in this study were compared with different recognized organizations such as WHO (Table 1). Table 2 below shows the lowest and highest levels of the analyzed parameters in water samples from two areas (Kilima-hewa and Mtoni). Table 3 depicts the relative proportions of the analyzed metals (in the percentage term). This is an indicator of the concentration of these ions in a sample sub-area relative to the total concentration (Annex) of the same ion in the entire respective study areas (Mtoni and Kilima-hewa) in percentage term.

\section{Calcium}

The levels of calcium from water samples had the range of 0.0045 $240.17 \mathrm{mgL}^{-1}$. The lowest concentration of calcium was recorded from Kilima-hewa area, while the highest level of calcium (site number 5) was measured for sample collected from Mtoni area. (Table 2 \& Figure 1). Generally, Mtoni water samples showed higher levels of calcium compared to water samples from Kilima-hewa area. Water samples from Mtoni areas showed higher levels of calcium with reference to WHO and CDWQ, and this accounts for $80 \%$ and $20 \%$ respectively (Table 3 ). The variation in the levels of calcium is likely to be attributed by the differences in geological nature between the two study areas. Mtoni soil is rockier compared to Kilima-hewa soil. This indicates that geological composition and the aquifer geochemistry can strongly affect both the ion occurrences and their levels in water sources. Calcium is most likely to be found at higher abundances at those areas, which are of coral, marble, chalk, rock, and limestone in nature.

\section{Cadmium}

The levels of cadmium in the study areas ranged between BDL - $48.59 \mathrm{mgL}^{-1}$. Highest concentration of cadmium was measured at sampling site number six of Kilima-hewa area (Table 2 \& Figure 2). Generally, the higher concentrations of cadmium were recorded

Table 3: Comparison of the analyzed parameters with recommended guidelines.

\begin{tabular}{|l|l|l|l|l|}
\hline Parameter & $\begin{array}{l}\% \text { above WHO } \\
\text { guideline }\end{array}$ & $\begin{array}{l}\% \text { above CDWQ } \\
\text { guideline }\end{array}$ & $\begin{array}{l}\% \text { above US. } \\
\text { NPDWR } \\
\text { guideline }\end{array}$ & $\begin{array}{l}\text { above EU } \\
\text { DWD } \\
\text { guideline }\end{array}$ \\
\hline $\mathrm{Ca}$ & $0^{\mathrm{a}} \& 80^{\mathrm{b}}$ & $0^{\mathrm{a}} \& 20^{\mathrm{b}}$ & $\mathrm{N} / \mathrm{A}$ & $\mathrm{N} / \mathrm{A}$ \\
\hline $\mathrm{Cd}$ & $20^{\mathrm{a}} \& 0^{\mathrm{b}}$ & $20^{\mathrm{a}} \& 0^{\mathrm{b}}$ & $20^{\mathrm{a}} \& 0^{\mathrm{b}}$ & $20^{\mathrm{a}} \& 0^{\mathrm{b}}$ \\
\hline $\mathrm{Cr}(\mathrm{III})$ & $\mathrm{N} / \mathrm{A}$ & $\mathrm{N} / \mathrm{A}$ & $\mathrm{N} / \mathrm{A}$ & $\mathrm{N} / \mathrm{A}$ \\
\hline $\mathrm{Cu}$ & $0^{\mathrm{a}} \& 0^{\mathrm{b}}$ & $0^{\mathrm{a}} \& 0^{\mathrm{b}}$ & $0^{\mathrm{a}} \& 0^{\mathrm{b}}$ & $0^{\mathrm{a}} \& 0^{\mathrm{b}}$ \\
\hline $\mathrm{Li}$ & $\mathrm{N} / \mathrm{A}$ & $\mathrm{N} / \mathrm{A}$ & $\mathrm{N} / \mathrm{A}$ & $\mathrm{N} / \mathrm{A}$ \\
\hline $\mathrm{Mg}$ & $0^{\mathrm{a}} \& 0^{\mathrm{b}}$ & $0^{\mathrm{a}} \& 0^{\mathrm{b}}$ & $0^{\mathrm{a}} \& 0^{\mathrm{b}}$ & $0^{\mathrm{a}} \& 0^{\mathrm{b}}$ \\
\hline $\mathrm{Pb}$ & $60^{\mathrm{a}} \& 0^{\mathrm{b}}$ & $60^{\mathrm{a}} \& 0^{\mathrm{b}}$ & $20^{\mathrm{a}} \& 0^{\mathrm{b}}$ & $60^{\mathrm{a}} \& 0^{\mathrm{b}}$ \\
\hline $\mathrm{Sr}$ & $\mathrm{N} / \mathrm{A}$ & $\mathrm{N} / \mathrm{A}$ & $\mathrm{N} / \mathrm{A}$ & $\mathrm{N} / \mathrm{A}$ \\
\hline $\mathrm{Zn}$ & $0^{\mathrm{a}} \& 0^{\mathrm{b}}$ & $0^{\mathrm{a}} \& 0^{\mathrm{b}}$ & $0^{\mathrm{a}} \& 0^{\mathrm{b}}$ & $0^{\mathrm{a}} \& 0^{\mathrm{b}}$ \\
\hline
\end{tabular}

${ }^{\mathrm{a}}$ and ${ }^{\mathrm{b}}$ represent the respective \% at Kilima-hewa and Mtoni respectively for the analyzed parameters; NA: No guideline available 


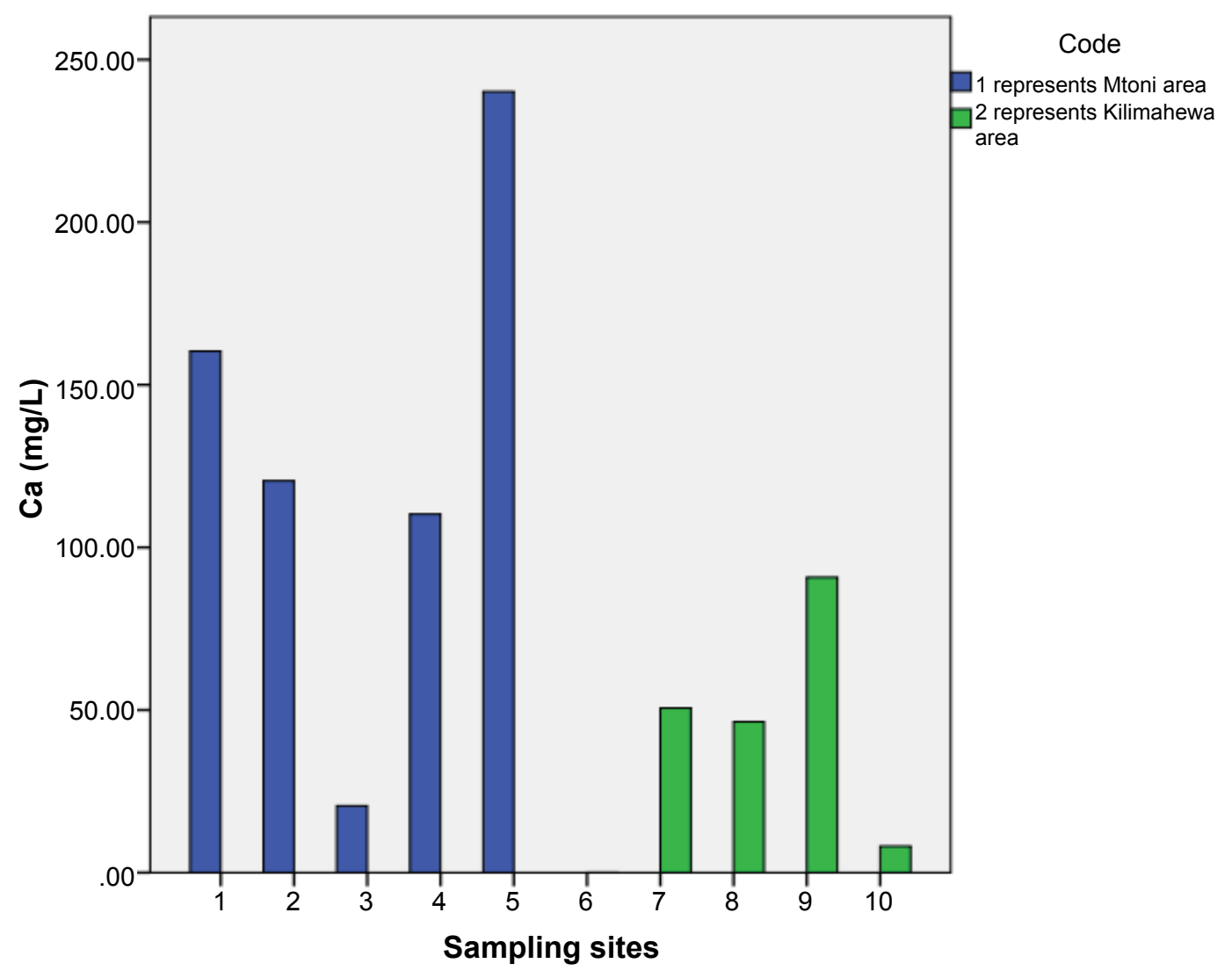

Figure 1: Concentrations of $\mathrm{Ca}$ in water sources in two study areas.

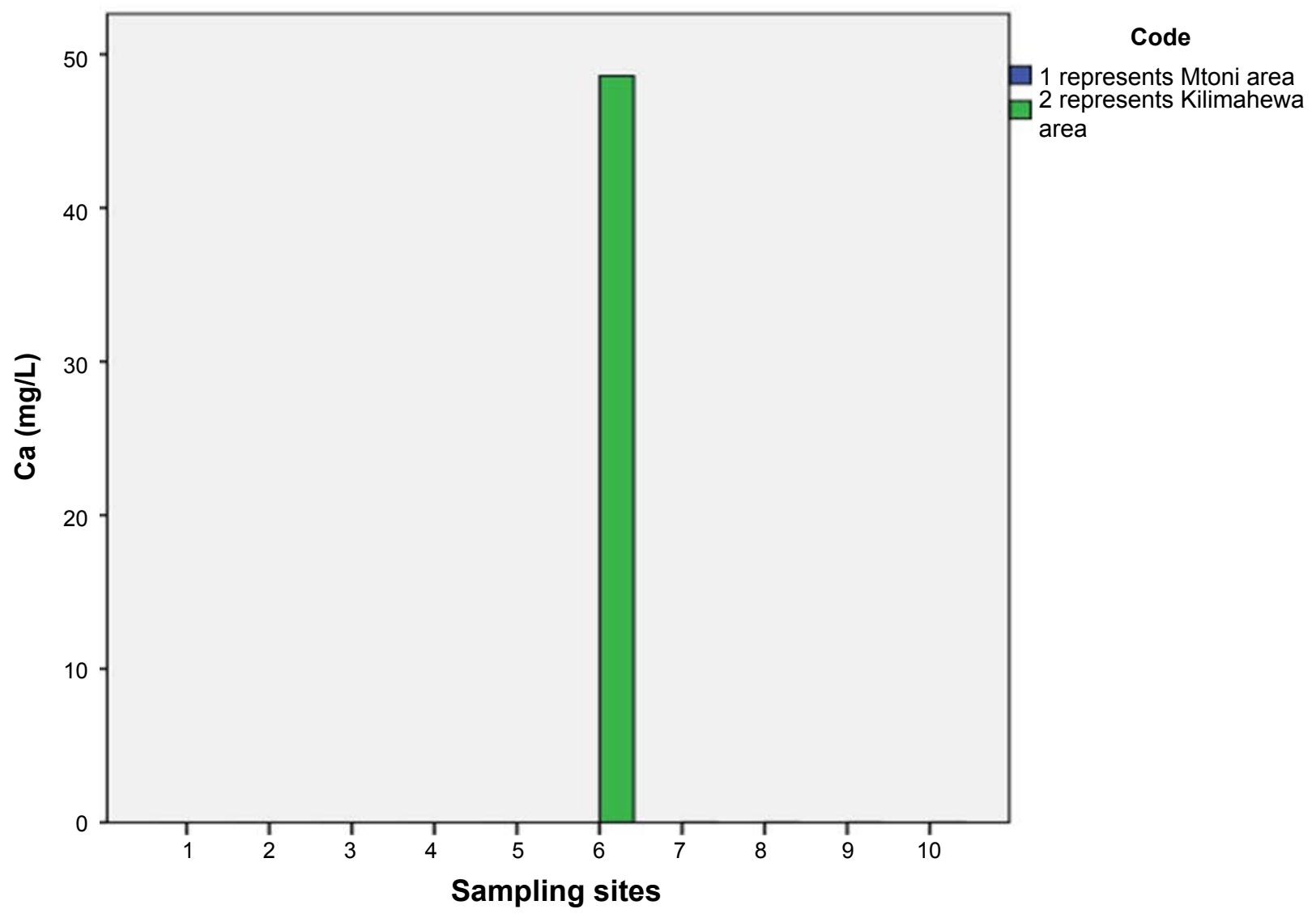

Figure 2: Concentrations of $\mathrm{Cd}$ in water sources in two study areas. 
from shallow wells around Kilima-hewa area. The concentrations of cadmium in water samples collected at Kilima-hewa sampling points showed $20 \%$ beyond the drinking water safe limit as recommended by the four organizations (Table 3). Among the anthropogenic origins of cadmium are fertilizers, pesticides [18]. These elevated levels of cadmium at the water sources are probably due to anthropogenic influence, such as dumping of electronic parts, and the lithium containing batteries closer to the water sources at Kilima-hewa premises. The use of cadmium containing insecticides might also have enhanced the elevation of cadmium near water source number six.

\section{Chromium III}

Chromium III in the study areas was found in the range of BDL $0.032 \mathrm{mgL}^{-1}$. Here again, the highest concentration of chromium was recorded from the same sampling area (Kilima-hewa), but it is the water site number 8 that depicted highest concentration of chromium III. (Table 2 and Figure 3). The metal chromium can occur naturally, but its uses, such as in chromium plating and in stainless steel might be of a significant contribution to observed levels of chromium in water sources. Overall, none of the analyzed water samples had concentration of chromium III above the recommended guideline safe limit for drinking water (Table 3). The percentage comparison for Chromium III was not done as no guideline is available for this ion.

\section{Copper}

The concentrations of copper in the water samples ranged between BDL - $0.0272 \mathrm{mgL}^{-1}$. Remarkably, as for cadmium, the highest concentration of copper was measured at sampling site number six of Kilima-hewa area (Table 2 and Figure 4). Nevertheless, none of the analyzed water samples had concentration of copper above the recommended guideline safe limits for drinking water (Table 3). The traces of copper in water samples might have been attributed by natural or anthropogenic sources.

\section{Lithium}

From the study areas, lithium had a range of $0.0004-0.0613 \mathrm{mgL}$ ${ }^{1}$. The highest concentration of lithium was measured at sampling site number nine of Kilima-hewa area (Table 2 and Figure 5). Currently, there is no guideline available as the safe limit recommended for lithium (Table 1). As lithium is among naturally occurring element, plants such as vegetables can be exposed to lithium metal to a significant level. Thereby, other living organisms might be involved as transporting media for lithium in a given environment. In the same way as for chromium III, the percentage comparison for lithium was not calculated.

\section{Magnesium}

The concentrations of magnesium in the water samples ranged between $0.0047-12.800 \mathrm{mgL}^{-1}$ (Table 2 and Figure 6). The lowest concentration of magnesium was recorded from Kilima-hewa areas (sampling number six), while the highest concentration was found for water sample number 4 from Mtoni areas. All of the groundwater samples showed percentages, which are well below the recommended guidelines. There might be very negligible anthropogenic influence for magnesium occurrence on these water sources. Thus, levels of magnesium measured in the analyzed water samples are likely due to natural sources.

\section{Lead}

In the study areas, levels of lead were found in the range of BDL - $0.0178 \mathrm{mgL}^{-1}$ (Table 2 and Figure 7). The highest concentration of lead was recorded from Kilima-hewa area, (sampling number 10).

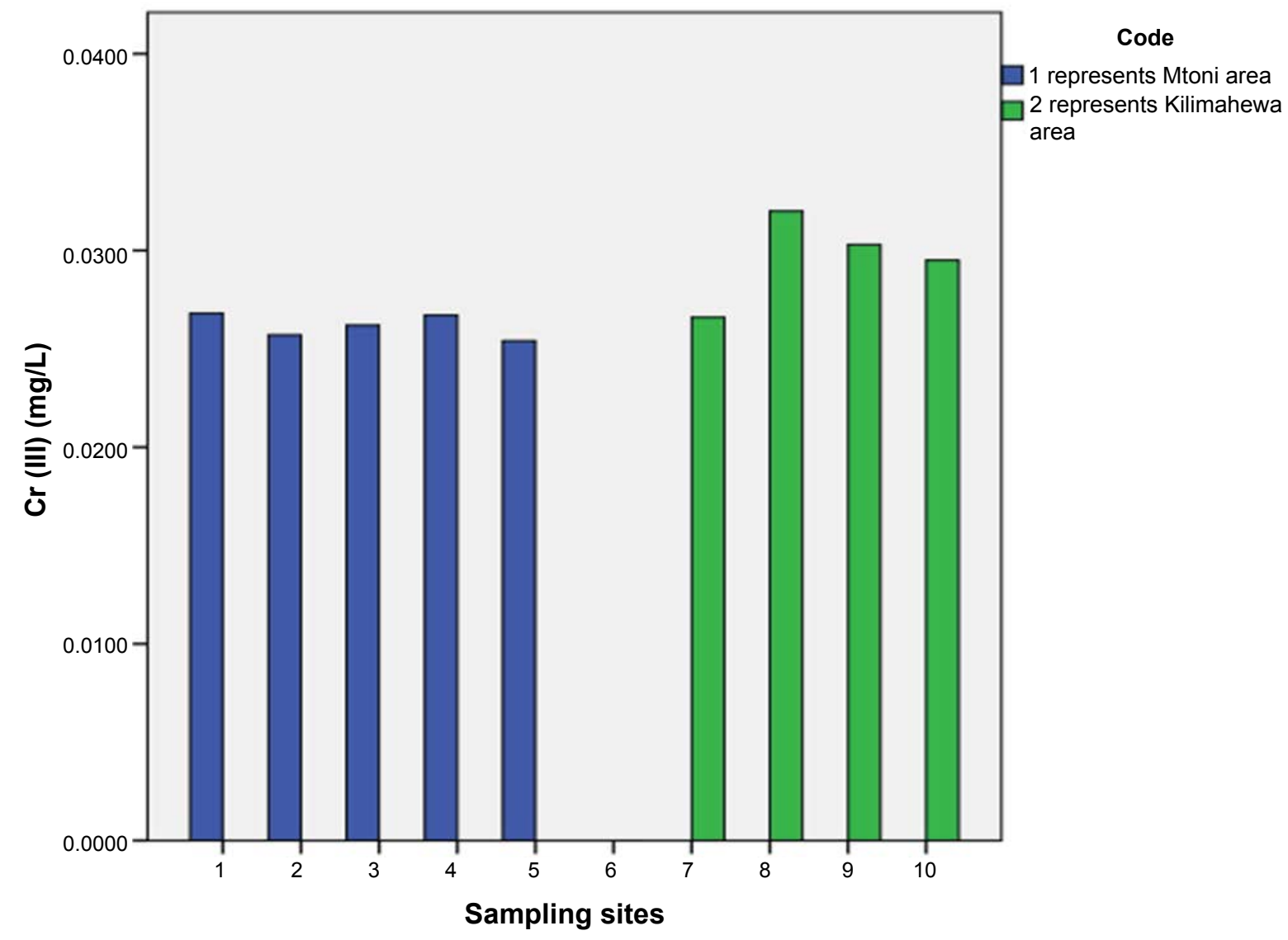

Figure 3: Concentrations of $\mathrm{Cr}$ (III) in water sources in two study areas. 


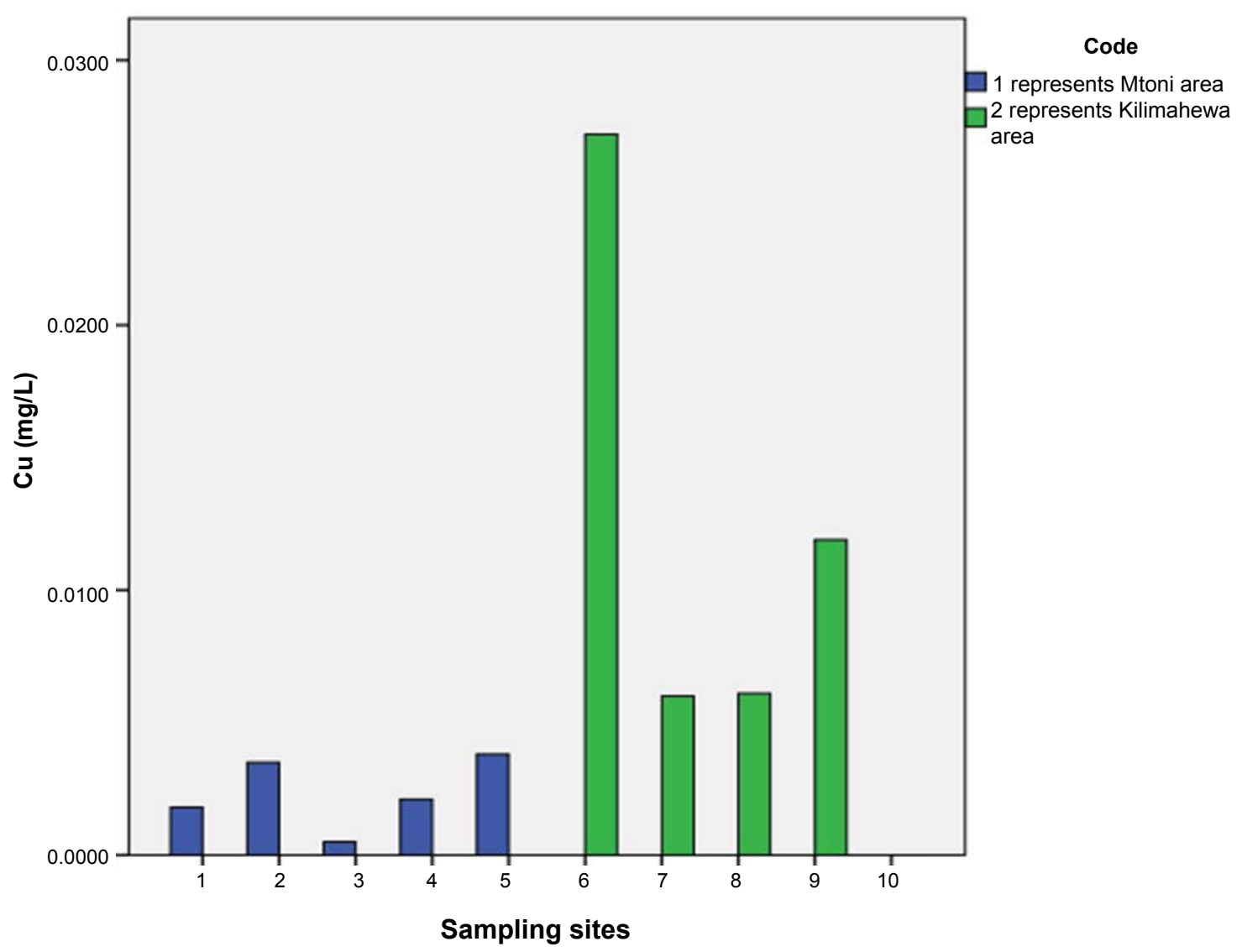

Figure 4: Concentrations of $\mathrm{Cu}$ in water sources in two study areas.

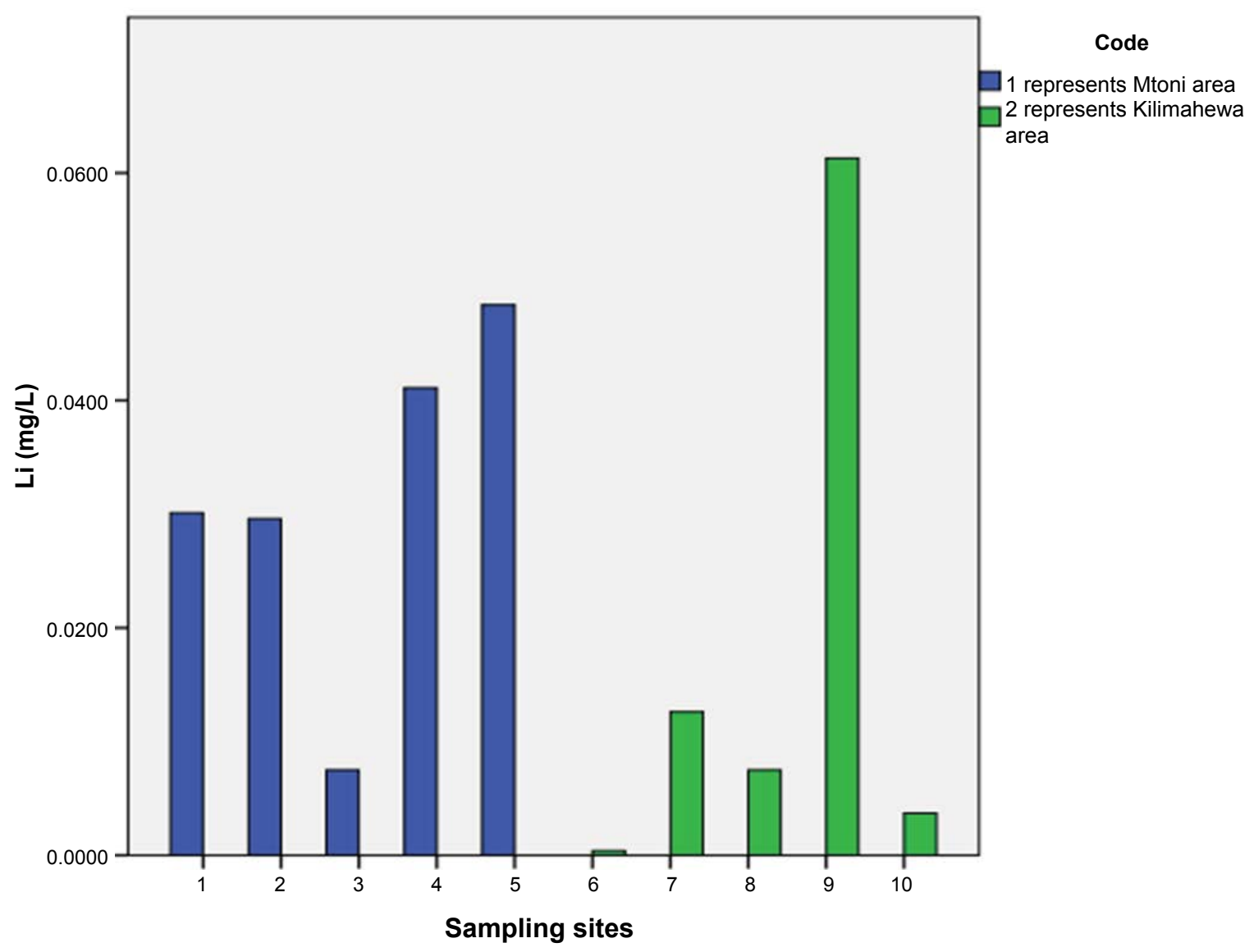

Figure 5: Concentrations of $\mathrm{Li}$ in water sources in two study areas. 


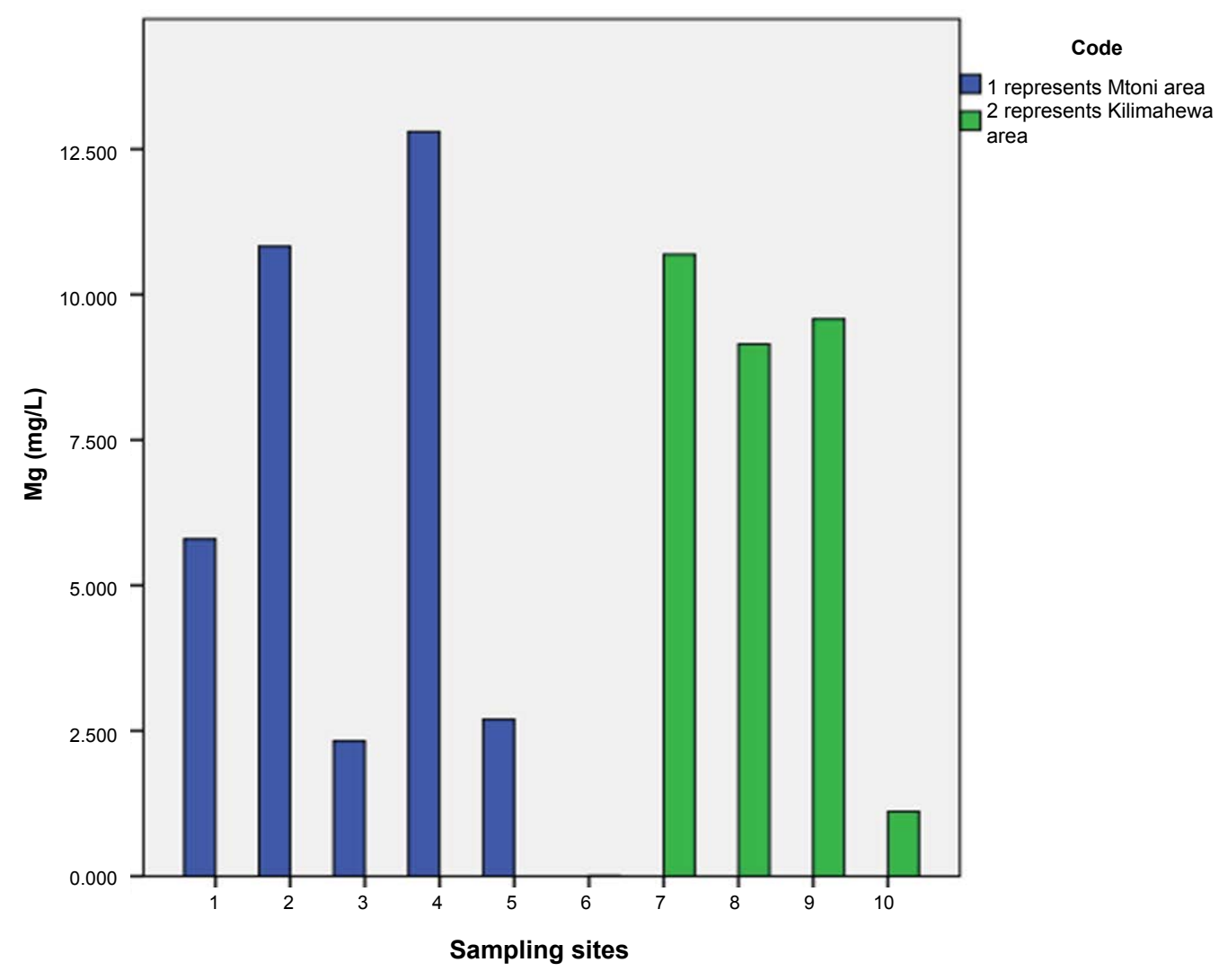

Figure 6: Concentrations of $\mathrm{Mg}$ in water sources in two study areas.

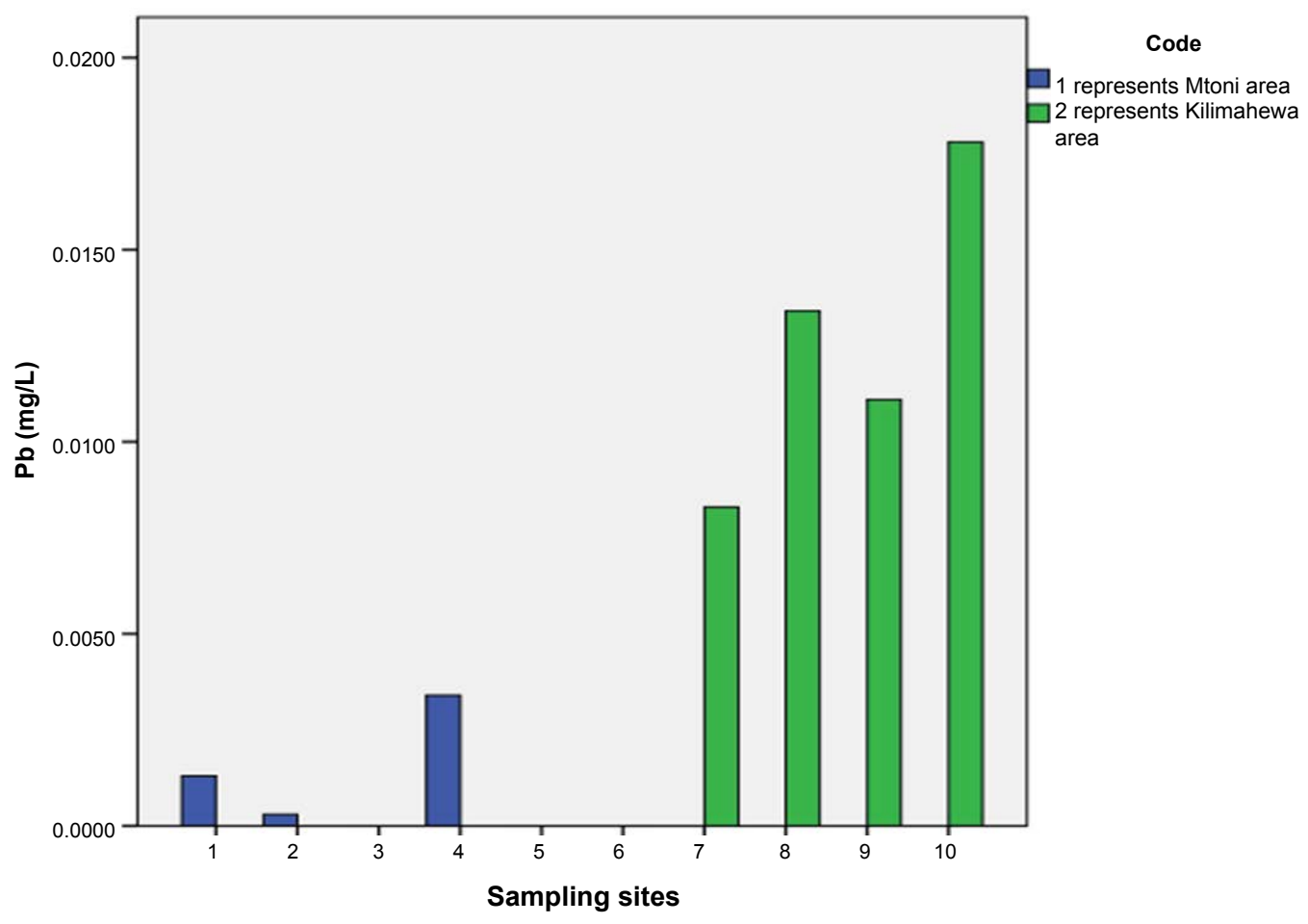

Figure 7: Concentrations of $\mathrm{Pb}$ in water sources in two study areas.

Generally, water samples from Kilima-hewa areas had concentrations of lead beyond the standard guideline limits set by WHO, CDWQ, US NPDWR, and EU. DWD, while, water samples from Mtoni areas had concentrations of lead, which are within the recommended limit set by these organizations (Table 3). Anthropogenic sources of lead might be the major and important contributor of the elevated levels of lead in water sources at Kilima-hewa. These sources include, leadbased paints, such as red-lead, application of lead $(\mathrm{Pb})$ in building materials, dumped lead acid batteries, tetraethyl lead used in gasoline, and lead containing insecticides. Nevertheless, airborne lead entering water sources via precipitation and is also among the key contributor of lead contaminants in groundwater sources. 


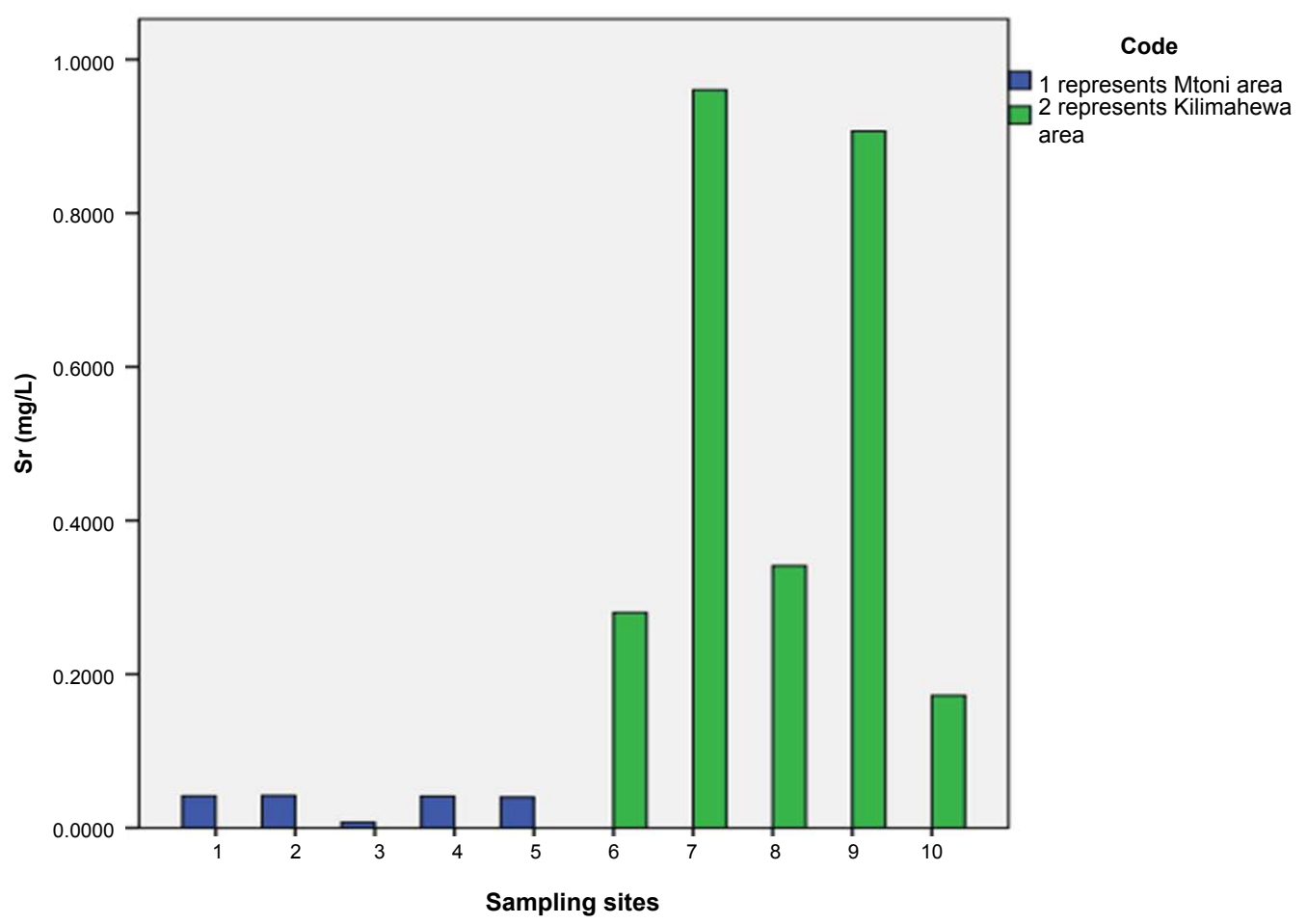

Figure 8: Concentrations of $\mathrm{Sr}$ in water sources in two study areas.

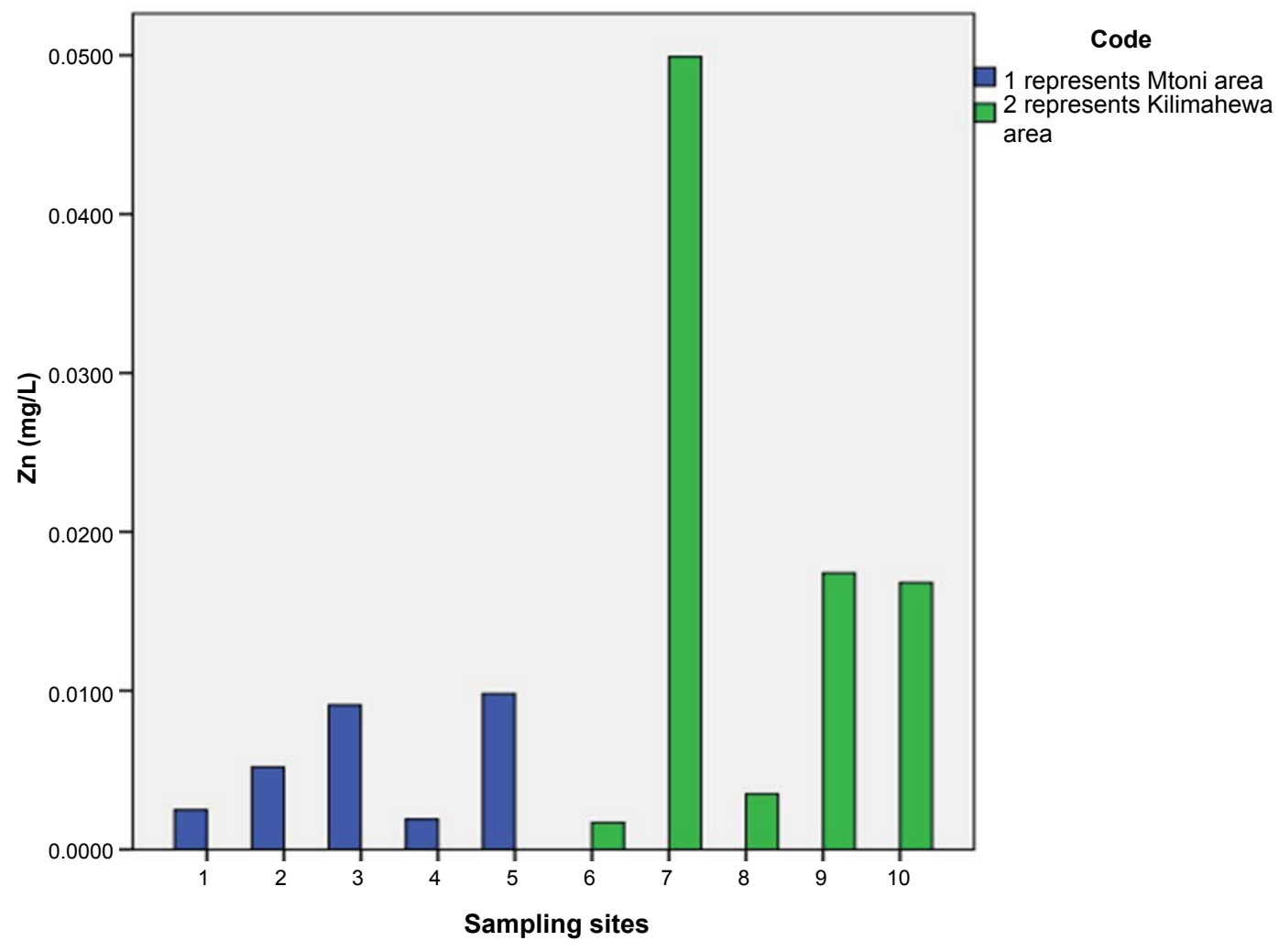

Figure 9: Concentrations of $\mathrm{Zn}$ in water sources in two study areas.

\section{Strontium}

The concentration range of strontium from water samples collected from the two Areas was 0.0073- $0.0499 \mathrm{mgL}^{-1}$ (Table 2 and Figure 8). The lowest and the highest concentrations of strontium were recorded from Mtoni and Kilima-hewa areas respectively. The occurrence of strontium in the environment is due to both natural and anthropogenic sources. From the earth crust, strontium is naturally released in to the atmosphere as result of dust particle and soil resuspension by wind and sea spray. Coastal areas are expected to have higher concentrations of strontium due to sea pray as a dominant natural process [19]. Anthropogenically, strontium in the groundwater aquifers might be caused by activities such as crushing, processing and dumping of strontium containing materials, burning 
of coal, agricultural activities that involve the use of strontium containing fertilizers.

\section{Zinc}

Zinc concentration in the study area ranged from 0.0017- 0.0499 $\mathrm{mgL}^{-1}$ (Table 2 and Figure 9). Both lowest and highest concentrations of zinc were recorded from Kilima-hewa area at sampling number 6 and 7 respectively. Overall, none of water samples from the study areas had zinc concentrations beyond standard guideline limits set by the accepted organizations.

\section{Conclusion}

In general, the values of analyzed parameter were within the recommended guidelines. However, the levels of cadmium and lead at Kilima-hewa sampling points are beyond the guideline levels, while the levels of calcium at Mtoni areas exceeded the recommended guidelines.

It is obvious that, not all of the chemicals with guideline values will be present in all water sources, or, definitely, in all sampling locations. If they do exist, they might not be found at levels of concern. Conversely, some chemicals without guideline values or not addressed in the guidelines may nevertheless be of justifiable national and international concern under particular circumstances.

As mineral analysis in the study areas was not conducted to assess the level of contaminants, therefore, this can be taken as an important limitation in the present study, and can be considered as an important area for further studies. Nevertheless, the policy makers are suggested to interpret the finding of this study with alarming. Furthermore, water authorities and other stakeholders need to apply different approaches and keeping priorities for good management of groundwater quality for the purposes of improving and protecting public health (Annex).

\section{Acknowledgment}

We highly acknowledge His Majesty Government of Brunei Darussalam for funding this project. We also thank $\mathrm{Hj}$ Jamil, $\mathrm{Hjh}$ Faridah, Hjh Rasiah, Azzlin, Najib, and other UBD chemistry laboratory staffs for their assiduous assistance.

\section{References}

1. Panno SV, Hackley KC, Hwang HH, Greenberg SE, Krapac IG, et al (2006) Characterization and identification of $\mathrm{Na}-\mathrm{Cl}$ sources in groundwater. Groundwater 44: 176-187.
2. Mohamed AAJ, Rahman IA, Lim LH (2014) Groundwater quality assessment in the urban-west region of Zanzibar Island. Environmental Monitoring and Assessment 186: 6287-6300.

3. Bhole V, Ramteke DS (2011) Preferential adsorption of heavy metals on activated carbon. Bangladesh J Sci Indus Res 46: 211-218.

4. Srinivas R, Prashant B, Ajit PS (2015) Groundwater Quality Assessment in Some Selected Area of Rajasthan, India Using Fuzzy Multi-criteria Decision Making Tool. Aquatic Procedia, International Conference on Water Resources, Coastal and Ocean Engineering (ICWRCOE- 2015) 4: 10231030.

5. Mohamed AAJ, Rahman IA, Said SA, Lim LH (2014) Occurrence of arsenic lead and thallium and beryllium in groundwater. Am J Environ Sci 10: 164170.

6. Great Lakes Environmental Center (2000) update of ambient water quality criteria for cadmium (draft). Prepared for US EPA.

7. Jarup $L$ (2002) Cadmium overload and toxicity. Nephrol Dial Transplant 17: 35-39.

8. Staessen J, Amery A, Bernad A, Bulpitt C, Buchet JP, et al. (1991) Blood pressure, the prevalence of cardiovascular diseases, and exposure to cadmium: A population study. Am J Epidemiol 134: 257-267.

9. Meyer I, Heinrich J, Lippold U (1999) Factors affecting lead and cadmium levels in house dust in industrial areas of eastern Germany. Sci Total Environ 234: 25-36.

10. Meyer PA, Pivetz T, Dignan TA, Homa DM, Schoonover J, et al. (2003) Surveillance for elevated blood lead levels among children-United States, 1997-2001. MMWR Surveill Summ 52: 1-21.

11. Robert HF (2012) Essentials of Environmental Health $2^{\text {nd }}$ Edn. Jones \& Bartlett Learning, Burlington.

12. Denkhaus E, Salnikow K (2002) Nickel essentiality, toxicity, and carcinogenicity. Crit Rev Oncol Hematol 42: 35-56.

13. (2015) Agency for Toxic Substances and Disease Registery (ATSDR).

14. Hotz C, Lowe NM, Araya M, Brown KH (2003) Assessment of the trace element status of individuals and populations: the example of zinc and copper. J Nutr 133: 1563S-1568S.

15. Piao F, Yokoyama K, Ma N, Yamauchi T (2003) Subacute toxic effects of zinc on various tissues and organs of rats. Toxico Lett 145: 28-35.

16. APHA (2005) Standard methods for the examination of water and waste water, $21^{\text {st }}$ edition. American Public Health Association, Washington, DC, USA

17. APHA (American Public Health Association) (2000) Standard methods for the examination of water and wastewater, New York.

18. Great Lakes Environmental Center (2000) Update of ambient water quality criteria for cadmium (draft) Prepared for US EPA.

19. Capo RC, Stewart BW, Chadwick OA (1998) Strontium isotopes as tracers of ecosystem processes: theory and methods. Geoderma 82: 197-225. 
Annex: Concentrations $\left(\mathrm{mgL}^{-1}\right)$ of the analyzed parameter at Mtoni and Kilima-hewa Zanzibar.

\begin{tabular}{|c|c|c|c|c|c|c|c|c|c|c|}
\hline Samlple & $\mathrm{Ca}$ & Cd & $\mathrm{Cr}$ (III) & $\mathrm{Cu}$ & Li & Mg & $\mathbf{P b}$ & $\mathrm{Sr}$ & $\mathrm{Zn}$ & Area \\
\hline 1 & 160.35 & $<\mathrm{DL}$ & 0.0268 & 0.0018 & 0.0301 & 5.798 & 0.0013 & 0.0416 & 0.0025 & Mtoni \\
\hline 2 & 120.47 & $<\mathrm{DL}$ & 0.0257 & 0.0035 & 0.0296 & 10.83 & 0.0003 & 0.0421 & 0.0052 & Mtoni \\
\hline 3 & 20.508 & $<\mathrm{DL}$ & 0.0262 & 0.0005 & 0.0075 & 2.325 & $<\mathrm{DL}$ & 0.0073 & 0.0091 & Mtoni \\
\hline 4 & 110.24 & $<\mathrm{DL}$ & 0.0267 & 0.0021 & 0.0411 & 12.8 & 0.0034 & 0.0411 & 0.0019 & Mtoni \\
\hline 5 & 240.17 & $<D L$ & 0.0254 & 0.0038 & 0.0484 & 2.697 & $<\mathrm{DL}$ & 0.04 & 0.0098 & Mtoni \\
\hline 6 & 0.0045 & 48.59 & $<\mathrm{DL}$ & 0.0272 & 0.0004 & 0.0047 & $<\mathrm{DL}$ & 0.2803 & 0.0017 & Kilima-hewa \\
\hline 7 & 50.62 & 0.0008 & 0.0266 & 0.006 & 0.0126 & 10.69 & 0.0083 & 0.9604 & 0.0499 & Kilima-hewa \\
\hline 8 & 46.38 & 0.0007 & 0.032 & 0.0061 & 0.0075 & 9.147 & 0.0134 & 0.3412 & 0.0035 & Kilima-hewa \\
\hline 9 & 90.76 & 0.0015 & 0.0303 & 0.0119 & 0.0613 & 9.579 & 0.0111 & 0.9067 & 0.0174 & Kilima-hewa \\
\hline 10 & 8.084 & 0.0007 & 0.0295 & $<D L$ & 0.0037 & 1.114 & 0.0178 & 0.1722 & 0.0168 & Kilima-hewa \\
\hline
\end{tabular}

DL: Detection Limit 